\title{
The Prospects of Enhancing Food Security in Kenya through the Demographic Dividend
}

\author{
Wanjiru Gichuhi ${ }^{1}$ and Alexander M. Nasiyo ${ }^{2}$ \\ Population Studies \& Research Institute, University of Nairobi, Nairobi, Kenya \\ wgichuhi2003@yahoo.com
}

\begin{abstract}
Kenya is starting to enter its window demographic dividend, under the assumption of declining fertility rates over the next several decades. The country has the opportunity to exploit the first demographic dividend by attracting and retaining youth in farming. However, studies show that Kenya is deriving very little demographic dividend in agriculture with an increasing proportion of the country's working age population being inactive. The main objective of this paper is to theoretically examine the demographic dividend, and how this window of opportunity can be utilized to enhancing food security in Kenya. Specifically, it examines the relationship between population growth and increasing food security, with reference to theories against, supporting and neutral. It further, describes Kenya's youth bulge, and how the bulge can be utilized to enhance food security. We also identify a number of mechanisms that can be applicable to propel the youth for food security in Kenya. The paper benefited immensely from secondary data sources and desk review for evidence.
\end{abstract}

Keywords: Harnessing demographic dividend, demographic transition, youth bulge, food security, agriculture

\section{Introduction}

Gribble \& Bremner (20/2) stipulates that the demographic dividend is the accelerated economic growth that may result from a rapid decline in a country's fertility and the subsequent change in the population age structure. With fewer births each year, a country's working-age population grows larger in relation to the young dependent population. Gribble \& Bremner further add that with more people in the labor force and fewer young people to support, a country has a window of opportunity for rapid economic growth if the right social and economic investments and policies are made in health, education, governance, and the economy. Thus, investments in today's youth population can position a country to achieve a demographic dividend, but the gains are neither automatic nor guaranteed.

Kenya is still working its way through the demographic transition (Ross, 2004). Kenya is at the intermediate stage and has the opportunity to exploit the first demographic dividend. The second dividend begins toward the end of the intermediate phase and extends through the late phase, but the policies for realizing the second dividend are best established during the intermediate phase. Population pyramids for Kenya in 2014 demonstrate the different population dynamics that are at work. The bulge is at the young dependent ages (high and low proportion of younger and older people, respectively) with all the burdens that they represent (Central Intelligence

Agency, 20I4). The youth (I5-34 years) comprise over two-thirds of the working-age population (KNBS, 20I5).

Studies show that almost 40 percent of Africa's population is under age 15 and have yet to enter their reproductive years (FAO, 20I5). Sub-Saharan Africa's population is projected to more than double from 856 million today to about 2 billion in 2050 (UN Population Division, 2010). Experts and researchers stipulate that population growth will greatly increase the amount of food needed to adequately feed subSaharan Africa's people (FAO, 20I0). Although progress has been made towards halving the proportion of its population suffering from hunger (MDG I), women's reproductive health lags behind and birth rates remain high in Kenya (Bremner, 20I2).

According to FAO (2009), almost two of every people in Kenya live in a rural area, relying principally on small-scale agriculture for their livelihood. Improving agriculture on small farms is crucial to reducing hunger. Studies across Africa confirm that the youth is the future of food security yet, few see a future for themselves in agriculture or rural areas (Omoju \& Abraham, 20I4; and Teller \& Hailemariam, $20 \mathrm{II})$. Kenya is deriving very little demographic dividend in agriculture with an increasing proportion of the country's working age population being inactive. 
Overall, there has been little interest on the question whether there has been a relationship between demographic dividend and food security. There are very few regional references on demographic dividend (Omoju \& Abraham, 20I4; Teller \& Hailemariam, 20 I I; Fadayomi, 20I I; and Olaniyan, et al., 20I2). When it comes to demographic dividend, these studies have only focused on policies neglecting other aspects like linking demographic dividend to food security, and youth involvement. In addition, demographic dividend and food security remain a subject of debate. Economist and demographers, for example, continue to disagree about whether population growth restricts, promotes, or is independent of food security. Proponents of each view can point to research evidence to support their cases.

The main objective of this paper is to theoretically examine demographic dividend, and how this window of opportunity can be utilized to propel the youth to increase food security in Kenya. Specifically, it examines the relationship between population growth and increasing food security, with reference to theories against, supporting and neutral. It further, describes Kenya's youth bulge, and how the bulge can be utilized to enhance food security. We also identify a number of mechanisms that can be applicable to propel the youth for food security in Kenya as informed by the conceptual framework in figure I.

The paper is divided into four sections. The first section is the introduction. The second section is the literature review and theoretical framework, which presents an overview of the demographic transition and theories about whether population growth restricts, promotes, or is independent of food security. Discussion of key issues is the focus on section three. In it, we examine the youth bulge in Kenya, and how the bulge can be utilized to enhance food security. The final section provides the conclusion and recommendations.

\section{Literature Review and Theoretical Framework The Demographic Transition and Window of Opportunity}

The demographic transition underlines the changes in age structures of a country's population. The transition is a demographic process where the first phase, starting from high birth and death rates consists of declining mortality rates leading to an increase in the younger age cohorts. The decline in mortality originated in improvements in medicine and public health. This development accelerated from the end of the Second World War for developing countries, especially benefiting the younger generation (Bloom, et al., 2003). The next phase of the demographic transition is a dramatic reduction in fertility rates. Declining fertility rates are a response to falling mortality rates. As the chance of survival for children increases fewer births are needed to realize the desired number of offspring. The lag between falling mortality and fertility rates results in population growth. The demographic transition causes population growth first to accelerate, then to decline and eventually when the transition is completed population growth will return to a constant (pretransition) level. This transition goes along with the transformation from a rural society to an urban society (van der Ven \& Smits, 20I I).

The demographic transition is illustrated in figure 2 , where the difference between the birth rate and the death rate is the population growth rate. As long as the birth rate is higher than the death rate, population growth is positive and so the population size keeps increasing. The demographic transition can be described by the four stages represented in figure I. According to HCSC-Geography-Online (20II) in stage I, high birth and high death rates. This would have included pre-industrial and there would have been low population growth. Stage 2 is characterized by high birth rates but the death rate falls quickly due to better health care, agricultural practices, and living standards. A number of African countries like Kenya are at this stage. Population increase is high. Stage 3 then illustrates the decline in birth rate and low death rate. Improvements in education, access to contraception and a richer more urban society lowers birth and fertility rates. The death rate is still declining but not as quickly. Stage 4 is characterized by low birth and death rates. Low rate of natural increase. Urban and developed countries like France and Australia are here. Finally, in stage 5 a result of an ageing population. Death rate increases and the birth rate is low. Countries have close to 0 population growth or a declining population, like Russia and Japan. 


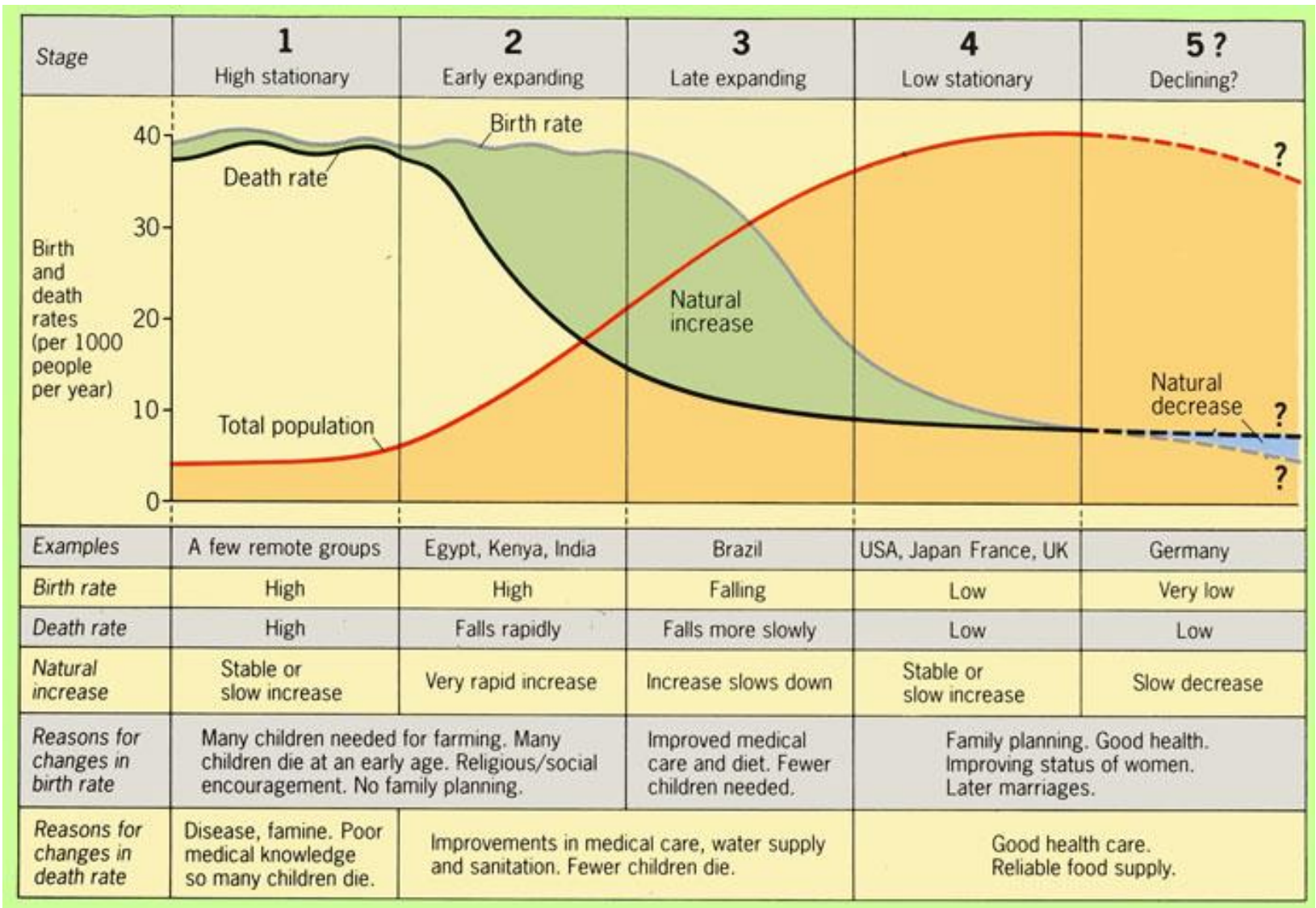

Figure I: The Demographic Transition (source: HCSC-Geography-Online, 20I I)

A demographic window of opportunity is created by the process of the demographic transition. The demographic window is the period in which the working-age population is growing and the young cohort decreasing while the old cohort is still small. The small groups of young and old population exert relatively low costs on society and with the large group of the working-age population there is an opportunity for an increase in per capita output. The increased per capita output made possible due to the window of opportunity is called demographic dividend (Bloom, et al., 2003). Eventually, population ageing will set in and the share of the working-age population will decline, make the demographic dividend a temporary phenomenon.

The demographic dividend can be created by the added productivity of the large group of the workingage population combined with the lower proportion of resources that have to be invested in child care, schooling and caring for the elderly. In other words, the children and the elderly produce much less than they consume while on the contrary working adults produce more than they consume on average (Mason, 2005). The demographic dividend or demographic gift arises due to the more rapidly increasing the working-age population relative to the total population. The increase in the working-age share is related to the decrease in the age dependency ratio. The child-aged (or youth-aged) population (under 15 years) and the old-aged population (65 years and over) decrease relative to the working age population during the demographic window of opportunity.

Boom et al. (2003) emphasized that understanding the relationship between population change and economic growth has taken on immense significance in recent years because of demographic trends in the developing world. The world's developing countries (home to the vast majority of the world's population) are in varying stages of a demographic transition from high to low rates of mortality and fertility. This transition is producing a boom generation that is gradually working its way through nations' age structures. In conjunction with the right kinds of policies, this phenomenon creates opportunities for food security in Kenya. For this reason, policymakers should benefit from a clearer understanding of the relationship between demographic dividend and increase food security, with the youth actively involved in the agriculture industry.

\section{Population Growth and Food Security}

\section{Population Growth Restricts Food Security}

Bloom et al. (2003) explain that concerns about rapid population growth voiced by demographers, and others were based largely on the assumption that population growth would "serve as a brake" on issues like food security. For instance, in the late 1940s, 
conservationists began to write about excessive population growth as a threat to food supplies and natural resources. Concern about the impact of rapid [population growth and high fertility motivated the widespread implementation of family planning programs in many areas of the developing world (Seltzer, 2002). Policymakers presumed that by helping to reduce high fertility, family planning programs would slow population growth, which in turn would contribute to food security by freeing resources that otherwise would be devoted to childbearing and by reducing strains on infrastructure and the environment.

The "pessimistic" theory traces its lineage to Thomas Malthus. Writing in the 1790s, Malthus asked whether "the future improvement of society" was possible in the face of the ever larger population. In a world with fixed resources for growing food, and slow technical progress. Malthus theorized food production would quickly be swamped by the pressures of a rapidly growing population. The available diet would then fall below subsistence level until population growth was halted by a high death rate. Living standards could only ever improve in the short term; before they set in motion more rapid population growth. The balance between population and income growth was the "great law of our nature (Malthus, 1798).

According to Bloom et al. (2003) for a time, it seemed the pessimists had the right answer. Innovations in agriculture, such as irrigation in China and potato cultivation in Ireland, were accompanied by vast increases in population that hampered improvements in living standards. Until 1700, income gaps between countries were fairly small and, even in 1820, real income levels in the advanced European nations were only about two to three times those found in Africa, Asia, and Latin America.

However, by the early 1980s, economists were beginning to reject the pessimist view. In response to these developments, organizations such as the National Academy of Sciences began to revise their earlier views, as economists' voices, with their greater faith in markets' ability to respond to population growth, no longer took a backseat to those of the social and biological scientists who previously dominated population thinking (National Research Council, 1986). Studies have weakened the pessimists' case; for example, economic theory had begun to give increasing importance to technology and human capital accumulation rather than to the old key growth factor of physical capital; and demographic theory started to look to the intermediate and long term, where the short-term effects of population growth were likely to have at least partly smoothed out.

\section{Population Growth has no Significant Effect on Food Security}

Most economic analysis has examined the statistical correlation between population and economic growth (food security) and found a little significant connection (Bloom, et al., 2003). Though countries with rapidly growing populations tend to have more slowly growing economies, this negative correlation typically disappears (or even reverses direction) once other factors such as country size, openness to trade, educational attainment of the population, and the quality of civil and political institutions are taken into account. In other words, when controlling for other factors, there is little cross-country evidence that population growth impedes or promotes food security (Bloom \& Freeman, 1986). These results justify population neutralism.

Although there are some variations within the neutralist school, for example, the National Research Council (1986) conceded that on balance slower population growth would be beneficial to the food security of most developing countries. In addition, many World Bank (200I) economists suggesting that in some countries bigger populations can boost food security; the overall tendency is to accord population issues a relatively minor place in the context of the wider policy environment.

\section{Population Growth can Propel Youth to Food Security}

Recent history has cast doubt on the pessimists' theory, for instance, famines have occurred, but Ehrlich's "hundreds of millions" of people have not starved. The famines that have occurred were largely caused by poverty and lack of funds within a section of the population to buy food rather than by any absolute shortage of food (Bloom, et al., 2003). Sen (1999) stipulated that there has never been a famine in a functioning democracy, whatever its population growth rate. Technological progress, in both agriculture and industry, has been more rapid than during any other time in human history. There have been equally dramatic social and institutional innovations: in the way people work, the standard of their education and health, and the extent to which they participate in the political process (Bloom, et al., 2003). These trends have supported the views of a group of "population optimists" who have sought to promote the idea that population growth can be an asset when it comes to food security. 
Population optimists' researchers argue that as (Kuznets, 1960; and Simon, 1981). Simon, in his influential book The Ultimate Resource (I98I), showed that rapid population growth can actually lead to positive impacts on food security (Simon, 198I). Boserup (198I) share similar sentiments by opining that people are resourceful and are stimulated to innovate, especially in adversity. When rising populations swamped traditional huntergatherer arrangements, slash-burn-cultivate populations increase, so does the stock of food agriculture emerged. When that, too, became inadequate, intensive multi-annual cropping was developed. More recently the Green Revolution, which has almost quadrupled world food production since 1950 using just I percent more land, was a direct reaction to population pressure (Department for International Development, 1997). For instance, without high yield agriculture, millions would have starved but, this has not been the case so far.

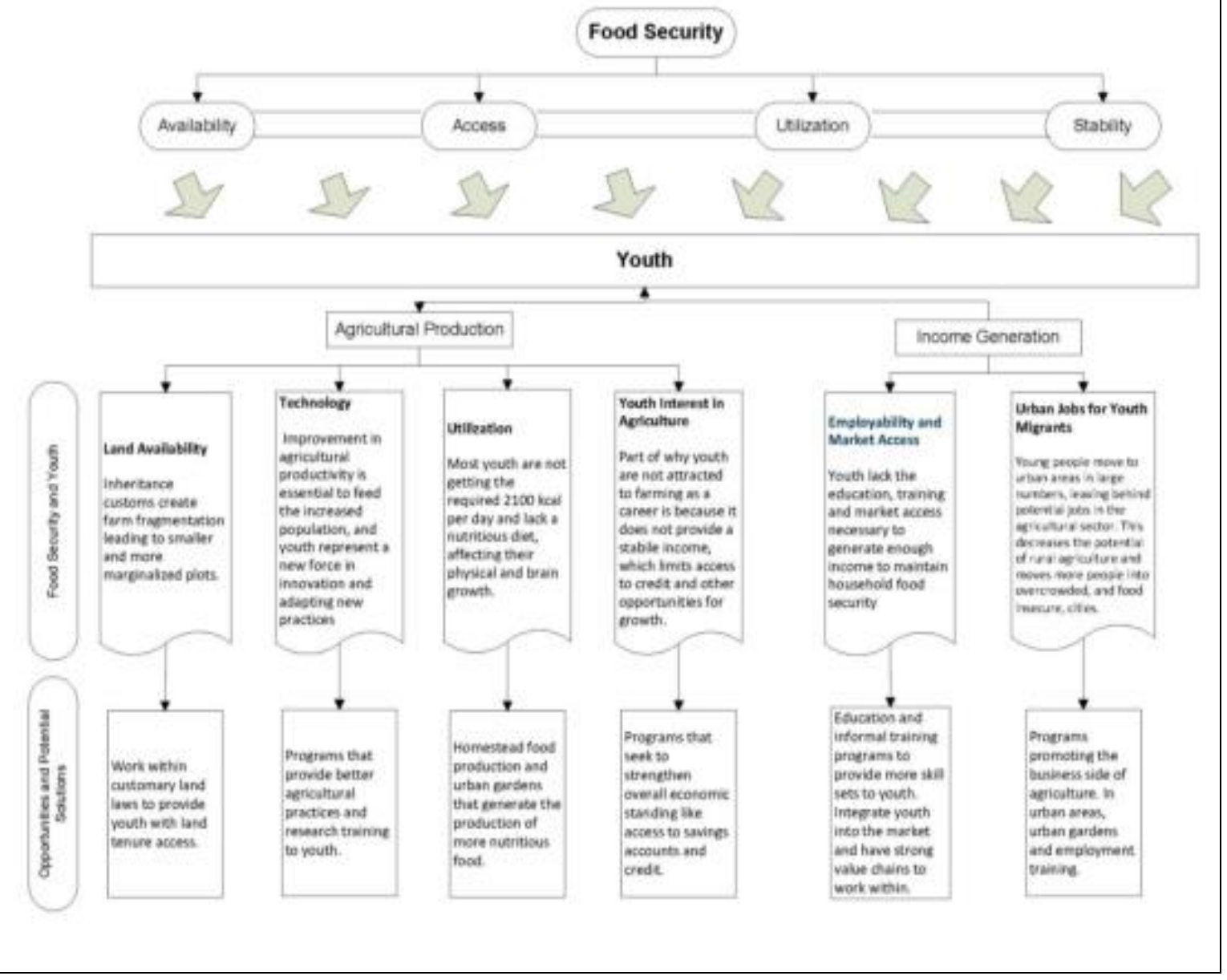

Figure I: Conceptual Framework (Source: Feighery, Ingram, Li, \& Redding, 20I I)

\section{Data Sources and Methods}

The main objective of this paper was to theoretically examine demographic dividend, and how this window of opportunity can be utilized to enhance food security in Kenya. The paper benefited immensely from secondary data sources and desk review of the evidence. Literature search used a mixture of approaches. First, we searched for all relevant materials on the demographic dividend in the Population Studies and Research Institute,
University of Nairobi and on the internet including, UAPS website. Second, a retrospective search was employed by identifying the most recent material. Third, we used citations to follow up references from useful articles, books and reading lists.

The paper used different sources of information. These included: journal articles (for example, Scandinavian Journal of Economics, Population and Development Review, and African Population 
Studies), and books. We also used research material and policy papers from government reports and

international organizations like United Nations. The demographic dividend was the keyword that was used on the internet through the search engines.

The paper restricted itself to demography and population studies discipline with a focus on the Africa region. In addition, we ensured that most of the articles and books that we dealt with were current issues (2006 to date), rather than taking a historical trends.

\section{Discussion}

\section{Kenya's Youth Bulge}

Kenya's 2010 Constitution defines youth as all individuals in the republic who are between 18 and 35 years. Currently, $78.31 \%$ of Kenyans are below 34 years old. It is estimated that $64 \%$ of unemployed persons in Kenya are youth.

Evidence show that $1.5 \%$ of the unemployed youth have formal education beyond secondary school level and the remaining over $92 \%$ have no vocational or professional skills training and the majority are found in rural Kenya (UNDP, 2013).

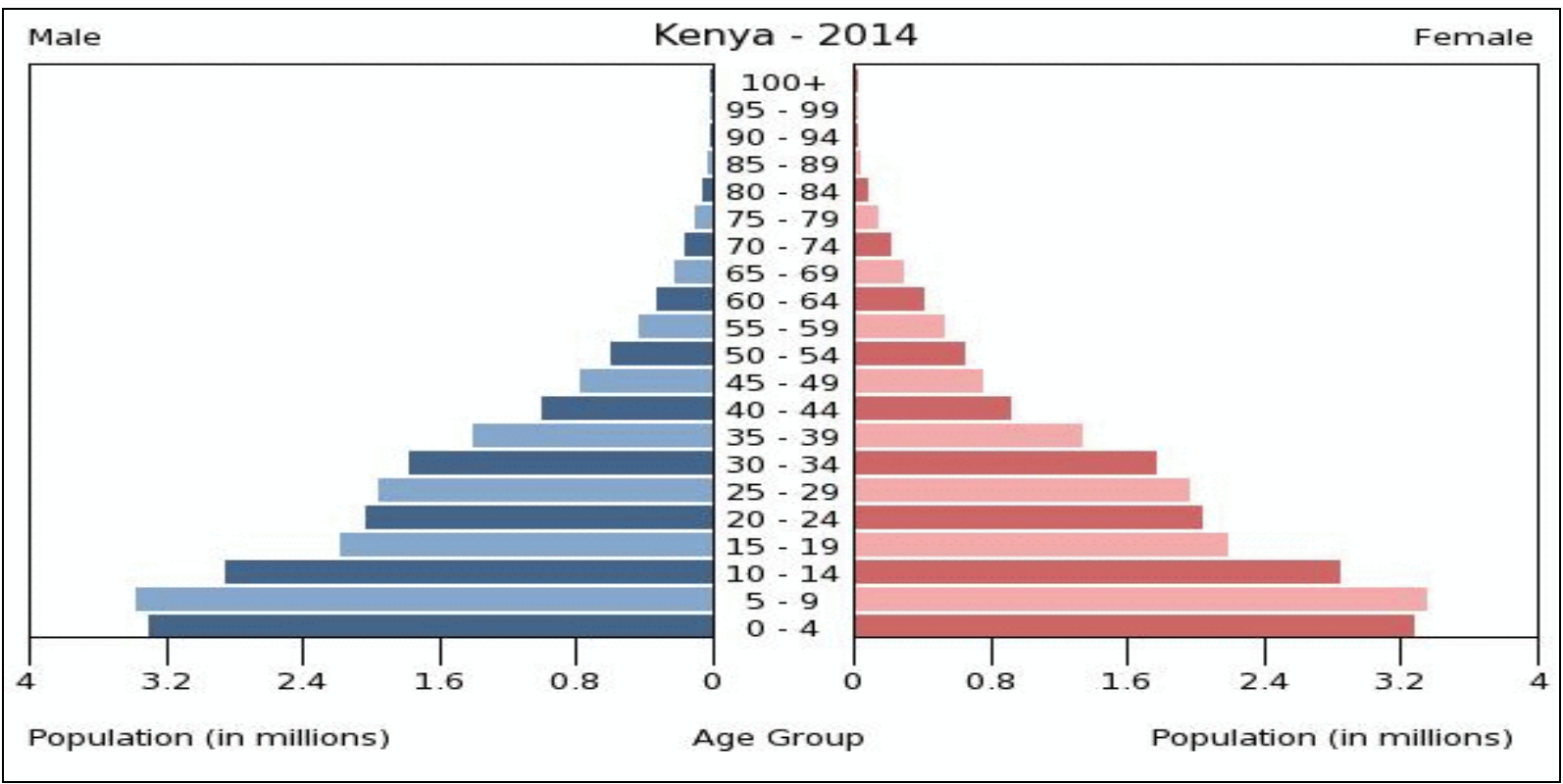

Figure 2: Population Pyramid for the Republic of Kenya, 2014 (Source: Central Intelligence Agency, 2014)

Developing countries like Kenya are still working their way through the demographic transition (as illustrated by Kenya's age pyramids in Figure 3 ). Olaniyan et al. (20/2) point out that during the early stage, the number of children rises rapidly as mortality falls.

It is envisaged that Kenya will experience a demographic shift/transition due to changing patterns in fertility, mortality and population growth as well as socioeconomic factors. As the $0-14$ age group matures into teenage-hood and young adulthood, and as many women continue to give birth later, space their children more or give birth to fewer children, the bulge will shift to the 15-34 year olds meaning that Kenya will transition from a 'child-rich' phase/child bulge to a 'young adult'/youth bulge population (Njonjo, 20I0).
According to Agbor et al. (20I2), Africa's youth population (15-24-year-olds) has been increasing faster than in any other part of the world. Moreover, 200 million people in Africa fall into this category, making up 20 percent of the population, 40 percent of the workforce, and 60 percent of the unemployed on the continent (Population Reference Bureau, 2009). Agbor et al. (20/2) further observe that youth in Africa hold great potential as drivers for economic growth through participation in labor markets and also as consumers. In addition, a young population can also be a resource that leads to innovation and supports governance and political reforms. However, a large youth population that is not gainfully employed can also be a liability, further undermining growth prospects (Agbor, et al., 20I2). Africa's youth present a formidable challenge that requires careful interventions. 
According to UNDP (20/3) estimates, the rate of population growth in Kenya peaked in the 1970s at a rate close to 5 percent. Since then, rates have been declining, but currently, Kenya's population growth is still close to 3 percent. According to estimates, it will not be until the 2050s and 2070s that rates will be below 2 percent and I percent, respectively (UNDP, 20I3). Such rapid population growth has meant that the balance between those of working age and those that cannot or should not work for age reasons is not most favorable. The dependency ratio reached a peak in the 1990s, and, although it has decreased since then, it registered rather high mark of 0.8 in 2010. It will only be towards the end of this century that the dependency ratio should be expected to reach its lowest point (UNDP, 2010).

UNDP (2013) promulgates that strong population dynamics imply a fast-growing youth population. After a steep rise, the growth rate of the youth population (those aged 15 to 34 years) peaked at about 4 percent per year between 1985 and 1990 . Since then, it has slowed down significantly, so that in 2010 the youth growth rate was lower than the growth rate of the adult population of working age (those aged 35 to 64 years). Accordingly, the proportion of young people within the working-age population stopped growing around 2000 and has been declining since then.

UNDP (20/3) concedes that Kenya has confronted strong demographic pressures. For instance, a large portion of the youth population remains unemployed and their economic status is being made worse by rising fuel and food costs. Even in the absence of large-scale revolts, youth unemployment represents an enormous cost to society in terms of lost potential growth and increased crime.

\section{Youth Bulge and Agriculture}

According to the Government of Kenya (20II), agriculture is the mainstay of the Kenyan economy and a key livelihood pillar for the majority. It directly contributes 26 per cent to the annual GDP and another 25 percent indirectly. The sector accounts for 65 percent of Kenya's total exports and provides more than 70 percent of informal employment in the rural areas. The sector comprises six subsectors, namely: industrial crops, food crops, horticulture, livestock, fisheries, and forestry.

Nyoro (2004) point out that the growth of the national economy is highly correlated to growth and development of the agricultural sector. In the first two decades after independence, the agricultural sector, and in turn the national economy, recorded the most impressive growth in sub-Saharan Africa at average rates of 6 per cent per annum for agriculture and 7 percent for the national economy (Government of Kenya, 20II), suggesting that increased and deliberate investment in agriculture will translate into growth of food security in the country.

According to the Government of Kenya (20II), the contribution of the subsectors to Agricultural Gross Domestic Product (AgGDP) and agricultural exports respectively as per 2009 data, industrial crops contribute 17 percent of the AgGDP and 55 percent of agricultural exports. Horticulture is now the largest subsector, contributing 33 per cent of the AgGDP and 38 percent of export earnings. Food crops contribute 32 percent of the AgGDP but only 0.5 percent of exports, while the livestock subsector contributes 17 per cent of the AgGDP and 7 per cent of exports. Livestock, fisheries, and forestry subsectors have huge potential for growth that needs to be exploited (Government of Kenya, 20II). Agriculture provides the single most important platform for expansion of employment, income generation and food security in Kenya.

About $65 \%$ of the Kenyan population lives in rural areas, with $70 \%$ of rural households dependent on agriculture as the main livelihood pillar (Government of Kenya, 20II). The agriculture sector holds an important key to poverty reduction through increased productivity, value addition, improved marketing and linkages to other sectors. Njonjo (2010) observes that youth constitutes key demographic domains of poverty. Increasingly coming into policy attention is the growing economic, social and political disempowerment of the youth. Failure to exploit the opportunities provided by the "youth bulge" not only shuts down a key economic window to national development but predisposes society to political and social instability.

Agriculture has largely remained unattractive to young people for a variety of reasons. These include low returns on time and input investments; limited access to land among the youth; and low investments in the infrastructure necessary for efficient value chains; among other reasons (Government of Kenya, 20II). However, there are emerging success stories of changing attitudes among young men and women on undertaking agriculture as a business. However to accelerate this transformation, there is need to address some structural and attitudinal factors that hold back participation of youth in agriculture. Efforts to exploit the first demographic dividend by attracting and retaining youth in farming to achieve food security in Kenya need to rally the potential of youth as a very significant demographic group. 


\section{Mechanism to Propel Youth in Food Security}

Bloom et al. (2003) posit that the demographic dividend is delivered through a number of mechanisms that can be applicable to propel the youth for food security in Kenya. The most important are labor supply, savings, and human capital.

\section{Labour Supply of Youth in Agriculture}

A study by Escudero \& Mourelo (20/3) stipulated that in 2011 , there were more than 8.5 million people between the ages of 15 and 24 in Kenya, comprising 37.4 percent of the working-age population and rising to over two-thirds when the population under the age of 34 is considered (Figure 4). This is close to 2 percentage points higher than the share of youth observed in Africa as a whole (35.5 per cent) and around II percentage points higher than the world figure (26.5 per cent). As such, Kenya has an expansive population pyramid (high and low proportion of younger and older people, respectively) as opposed to the constrictive population pyramid (low proportion of young people and ageing population) observed for the world as a whole.

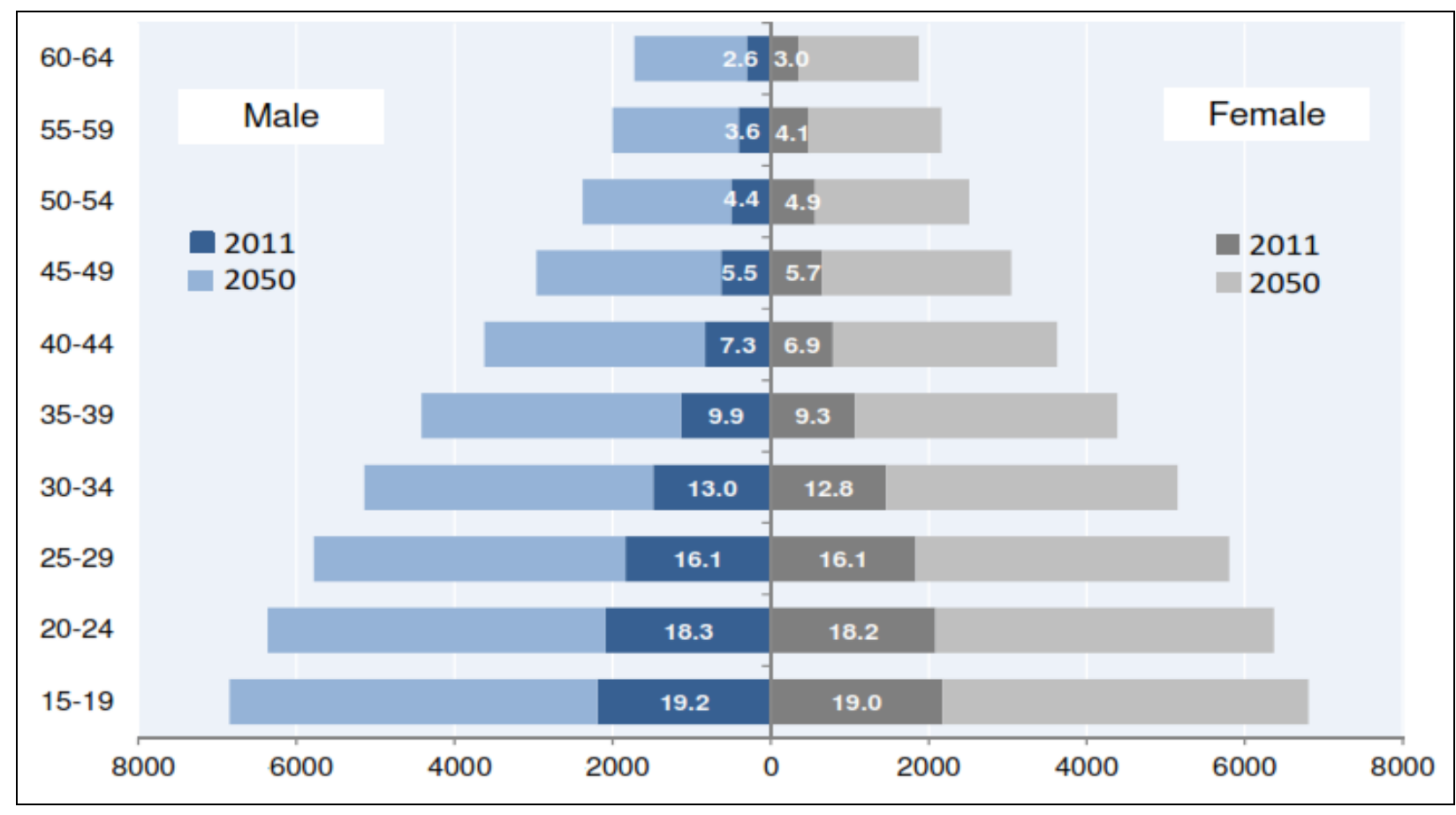

Figure 4: Kenya's working-age population by sex and age group, $20 \mathrm{II}$ and 2050 (in thousands) (Source: UNDESA, 20II)

According to UN World Population Prospects (UNDESA, 20II), by 2050 the number of youth in Kenya will reach 17.9 million, which is more than double the figure of $201 \mathrm{I}, 18.4$ percent of the estimated overall population and 30 percent of the estimated working-age population. This means as well that between $20 \mathrm{II}$ and 2050, the working-age population will increase, on average, by more than 950,000 people per year.

Bloom et al. (2003) concede that the demographic transition affects labor supply in two ways. First, there is an essentially mechanical effect, based on the regular and inevitable aging of the baby-boom generation. When this generation is between 15 and 64 , it is more likely to be working, thus lowering the ratio of dependents to non-dependents. During the peak working years of 20 to 54 , this effect is especially strong. The number of youth ( 15 to 34 years) who would like to practice farming (labor supply) therefore gets bigger. It is evident from the literature that agriculture is the mainstay of the Kenyan economy and a key livelihood pillar for the majority (Government of Kenya, 20I I).

\section{Saving and Food Security among Youth}

Sherraden \& McBride (2010) promulgate that over the last 20 years, a growing body of evidence has shown that building assets, and specifically savings, can have a range of positive social and economic impacts on individuals and households, including those with low incomes. Although much of this research has been conducted in industrialized 
countries, recent experiments in developing countries have begun to show links between youth owned savings accounts and positive changes in attitudes and behaviors among low-income and/or socially disadvantaged youth (YouthSave Initiative, 2010). In principle, appropriately designed and effectively delivered savings services could contribute to a variety of developmental goals, from economic and social empowerment at the micro level to broader inclusion and opportunity at the macro level.

The demographic transition encourages the growth of savings, thus improving a country's prospects for food security. The young and the old consume more than they produce, whereas workingage (including the youth) people tend to have a higher level of economic output and also a higher level of savings (Kelley \& Schmidt, 1995). However, the literature reveals that people tend to save more between the ages of 40 and 65 when they are less likely to be investing in their children and the need to prepare for their retirement is becoming more pressing (Meltzer, 1992). Thus, incentives to make farming activities attractive can reinforce this tendency to save among the youth. For instance, increased access to land among the youth make both farming and saving easier and more attractive. Personal savings grow and serve as a partial resource for industrial investments that fuel economic growth and food security.

Research on Tap and Reposition Youth (TRY) (a multi-phase youth savings initiative launched in 1998 by the Population Council and the K-Rep Development Agency (KDA) in low-income and slum areas of Nairobi) found participation in the youth savings program to be positively associated with higher income, savings, and household asset levels (Erulkar \& Chong, 2005). For example, on average, participants who opened a formal savings account doubled their savings from 23 USD to 44 from 2001 to 2004. By the pilot's end TRY participants also had significantly larger savings than nonparticipants (USD 95 vs. USD 67, respectively). And they were significantly more likely to: I) have at least seven or more household assets; 2) have savings, and significantly higher savings; and 3) keep their savings in a safer place than non-participants (YouthSave Initiative, 2010).

\section{Human Capital to Expand Agriculture Sector}

On human capital, the demographic transition has significant effects on investments in human capital, effects which are the least tangible, but may be the most significant and far-reaching (Bloom, et al., 2003). The demographic transition begins with changes in mortality that result in a young population that goes to live longer and stay healthier. According to Bloom \& Freeman (1986) a longer life expectancy causes fundamental changes in the way that young people live. Attitudes about education, family, retirement, the role of women, and work all tend to shift. A society, especially if it is taking full advantage of the demographic dividend, is certain to experience deep-rooted changes in its culture, as its people become more valuable assets. Take agriculture, for example, the positive correlation between agriculture and employment is well-known. In Kenya, agriculture directly contributes 26 per cent to the annual GDP and another 25 percent indirectly. The sector accounts for 65 percent of Kenya's total exports and provides more than 70 percent of informal employment in the rural areas (Government of Kenya, 20I I).

ljere (1992) concedes that youths have the potential to overcome some of the major constraints to expanding animal production in developing countries such as pest control, feeding, genetic improvement and protection against predators because they are often more open to new ideas and practices than adult farmers. They play an important role in awareness emanating on different subjects. In addition, FAO (1990) concluded that mobilizing the youths for national development is a common phenomenon amongst the western and developing countries. In such countries as Great Britain, Netherlands, Denmark, Germany, the United States of America and Tanzania, the involvement of youths in agricultural production through youth programmes had contributed significantly to the agricultural development and empowering the citizenry and youths to always meet the full needs and deep-seated aspiration to be self-sufficient in food production. Indeed, since the youths are the future of any society, the government must determine at both rural and urban level the sectors with growth potential and develop youth skills that will serve labour demand.

\section{Conclusion and Recommendations}

The paper has shown that the demographic window of opportunity now present will not last long and will not be repeated. It is expected that in the next $10-$ 20 years the window will begin to close in subSaharan Africa, including Kenya and favourable policies take the time to establish and take effect. Investments in education, health and job creation are vital among the youth, as are policies that favor the fertility declines that have created and sustained the window. It is evident that youth is much better positioned to adapt to new and changing technology, they can bring their creativity and energy to the agricultural industry. While acknowledging that issues 
of youth and youth employment are rising up the international policy agenda, there remains a low level of policy and investment intervention that focuses explicitly on the demographic dividend and youth employment opportunities in the agricultural sectors.

Policymakers can use the demographic dividend to begin to shift resources toward broadening youth access to the agricultural sector, for example, work within customary land laws to provide youth with land tenure access, and programs that seek to strengthen overall economic standing like access to savings accounts and credits. More so, there is a need to inject a number of innovations in agriculture in order to accelerate its transformation from a noneconomic traditional means of livelihood, to a profitable vibrant sector that can attract new ideas and energies that are represented by the youth (Omolo, 2012). These new ideas can include programs that provide better agricultural practices and research training to youth and programs promoting the business side of agriculture in urban areas, urban gardens, and employment training.

Consequently, failure to act on the demographic dividend could have a damaging effect on future prospects, as unemployment rises, the social fabric crumbles, and rising numbers of old people begin to overwhelm available resources. Embracing and understanding demographic challenges must, therefore, be a priority for all governments.

\section{References}

Agbor, J., Taiwo, O. \& Smith, J., 20I2. Sub-Saharan Africa's Youth Bulge: A Demographic Dividend or Disaster?. In: Foresight Africa: Top Priorities for the Continent in 20/2. Washington D.C.: The Brookings Institution, pp. 9-II.

Bloom, D., Canning, D. \& Graham, B., 2003. Longevity and Life-cycle Savings. Scandinavian Journal of Economics, 105(3), pp. 319-338.

Bloom, D. E., Canning, D. \& Sevilla, J., 2003. The Demographic Dividend: A New Perspective on the Economic Consequences of Population Change, Pittsburgh, PA: A RAND Program of Policy-Relevant Research Communication.

Bloom, D. \& Freeman, R., 1986. The Effects of Rapid Population Growth on Labor Supply and Employment in Developing Countries. Population and Development Review, p. 38|-4|4.

Boserup, E., 198I. Population and Technological Change: A Study of Long-Term Trends. Chicago: University of Chicago Press.

Bremner, J., 2012. Population And Food Security: Africa's Challenge, s.l.: Population Reference Bureau.
Central Intelligence Agency, 2014. The World Fact Book, Washington DC: Central Intelligence Agency.

Department for International Development, 1997. Poverty and the Environment, United Kingdom: Department for International Development.

Erulkar, A. \& Chong, E., 2005. Evaluation of a savings and microcredit program for vulnerable young women in Nairobi, Nairobi: Population Council.

Escudero, V. \& Mourelo, E. L., 20I3. Understanding the drivers of the youth labour market in Kenya, Geneva: International Labour Office.

Fadayomi, T., 20II. The demographic bonus: how prepared is Africa for the gains?. African Population Studies, 25(2), pp. 226-249.

FAO, 2009. The state of food and agriculture: Livestock in the balance, Rome: Food and Agricultural Organization of the United Nations.

FAO, 2010. The State of Food Insecurity in the World: Addressing Food Insecurity in Protracted Crises, Rome: Food and Agriculture Organization of the United States.

FAO, 2015. Regional overview of food insecurity: African food security prospects brighter than ever., Accra: FAO.

Government of Kenya \& NCPD, 2014. Demographic Dividend Opportunities for Kenya: Results from the DemDiv Model, Nairobi: National Council for Population and Development and Health Policy Project.

Government of Kenya, 201 I. Economic Survey 20II, Nairobi, Kenya: Kenya National Bureau of Statistics.

Gribble, J. N. \& Bremner, J., 20I2. Achieving a Demographic Dividend. Population Bulletin, pp. 67 (2): I- 13.

HCSC-Geography-Online, 201I. 201I Human Population: Demographic Transition Model. [Online]

Available at: http://hcsc-geographyonline.wikispaces.com/20I I + Human + Population [Accessed I January 2016].

ljere, M., 1992. Leading issues in rural development., Enugu: ACENA Publisher Ltd..

ILO, 20II. 'Key Indicators of the Labour Market (KILM), 7th edition, Geneva: International Labour Organization.

Kelley, A. \& Schmidt, R., 1995. Aggregate Population and Economic Growth Correlations: The Role of the Components of Demographic Change. Demography, Volume 32, p. 543-555.

KNBS, 2015. Economic Survey 2015, Nairobi: Kenya National Bureau of Statistics/Republic of Kenya.

Kuznets, S., 1960. Population Change and Aggregate Output. In: Demographic and Economic Changes 
in Developed Countries. Princeton, N.J.: Princeton University Press.

Lee, R. \& Mason, A., 2006. What Is the Demographic Dividend?. Finance and Development, p. 43 (3).

Malthus, T. R., 1798. Essay on the Principle of Population, As It Affects the Future Improvement of Society with Remarks on the Speculation of Mr. Godwin, M. Condorcet, and Other Writers. 1982 edition ed. Harmondsworth, Middlesex, UK: Penguin Classics.

Mason, A., 200I. Population Change and Economic Development in East Asia: Challenges Met, Opportunities Seized. Stanford: Stanford University Press.

Mason, A., 2005. Demographic Transition and Demographic Dividends in Developed and Developing Countries, Presented at United Nations Expert Group Meeting on Social and Economic Implications of Changing Population Age Structures. Mexico City, United Nations.

Meltzer, D., 1992. Mortality Decline, the Demographic Transition, and Economic Growth, Chicago: University of Chicago, Department of Economics.

National Research Council, 1986. Population Growth and Economic Development: Policy Questions. Washington, D.C.: National Academy Press.

National Research Council, 1986. Population Growth and Economic Development: Policy Questions, Washington, D.C.: National Academy Press.

Njonjo, K., 20I0. Youth Fact Book, Infinite Possibility or Definite Disaster?. Nairobi, Kenya, Institute of Economic Affairs.

Nyoro, J., 2004. National and Regional Markets. In Proceedings of the 6th ICA Regional Workshop on Agricultural Marketing held at the Cooperative College of Kenya. Nairobi, International Cooperative Alliance Regional Office for Africa.

Olaniyan, O., Soyibo, A. \& Lawanson, A. O., 20I2. Demographic transition, demographic dividend and economic growth in Nigeria. African Population Studies, 26(2), pp. 159-176.

Omoju, O. E. \& Abraham, T. W., 20I4. Youth bulge and demographic dividend in Nigeria. African Population Studies, 27(2), pp. 352-360.

Omolo, J., 2012. Youth Employment in Kenya: Analysis of Labour Market and Policy Interventions. FES Kenya Occasional Paper, pp. I:I-23.
Population Reference Bureau, 2009. Population Reference Bureau: World Population Data Sheet 2009, Washington, DC.: Population Reference Bureau.

Ross, J., 2004. Understanding the Demographic Dividend, Washington, DC: POLICY Project.

Seltzer, J., 2002. The Origins and Evolution of Family Planning Programs in Developing Countries, Santa Monica,CA: RAND MR- 276.

Sen, A., 1999. Development as Freedom. New York: Oxford University Press.

Sherraden, M. \& McBride, A., 20I0. Striving to Save: Creating Policies for Financial Security of LowIncome Families, Michigan: University of Michigan Press.

Simon, J., 1981. The Ultimate Resource. Princeton, N.J.: Princeton University Press.

Teller, C. H. \& Hailemariam, A., 20II. The uniqueness of the Ethiopian demographic transition within sub-Saharan Africa: multiple responses to population pressure, and preconditions for rural fertility decline and capturing the demographic dividend. African Population Studies, 25(2), pp. 362-380.

UN Population Division, 2010. World Population Prospects, New York: UN Population Division.

UNDESA, 2011. World Population Prospects: The 2010 Revision, New York: United Nations Publication.

UNDP, 2010. Kenya National Human Development Report 2009: Youth and Human DevelopmentTapping the Untapped Resource, Nairobi: United Nations Development Programme.

UNDP, 2013. Kenya's Youth Employment Challenge, New York: United Nations Development Programme.

van der Ven, R. \& Smits, J., 20II. The demographic window of opportunity: age structure and subnational economic growth in developing countries, HK Nijmegen: Nijmegen Center for Economics (NiCE).

World Bank, 200I. The 200I World Bank World Development Indicators, Washington, D.C.: World Bank.

YouthSave Initiative, 2010. Youth Savings in Developing Countries Trends in Practice, Gaps in Knowledge , Washington DC: Youthsave Consortium. 